\title{
An explanatory review of audit market concentration and auditor workload in Malaysia
}

\author{
Ali Raza ${ }^{a^{*}}$, Wan Nordin Wan Hussin ${ }^{a}$ and Jamaliah Abdul Majid
}

${ }^{a}$ Othman Yeop Abdullah Graduate School of Business, Universiti Utara Malaysia, Malaysia ${ }^{b}$ School of Accountancy, College of Business, Universiti Utara Malaysia, Malaysia

\begin{tabular}{l}
\hline C H R O N I C L E \\
\hline Article history: \\
Received March 112019 \\
Received in revised format \\
March 242019 \\
Accepted April 142019 \\
Available online \\
April 162019 \\
\hline Keywords: \\
Audit Market \\
Concentration Ratio \\
Capital Market \\
Big 4 Audit Firms \\
Auditor Workload \\
Staffing Ratio
\end{tabular}

\section{A B S T R A C T}

\begin{abstract}
The purpose of this study is to provide updated information and facts about the Malaysian audit market concentration and auditor workload. The global auditing services market is presently dominated by a group of four audit firms which known as Big 4; namely Deloitte, PriceWaterhouseCoopers, Ernst \& Young and KPMG. The audit industry in Malaysia offers several exemptions, as observed that two of non-big 4 audit firms succeeded to make their place into the Malaysian top 4. The study examined the audit firms share based on the number of audits and included all Malaysian public listed companies from 2012 to 2016. The findings indicate that the Malaysian audit market falls into the category of loose oligopoly and controlled by 8 audit firms. It is noted that the market share of the Big 4 in Malaysia have been reduced over a five-year period 2012-2016, and these firms mainly focusing more on large or more established clients. The examination related to auditor workload suggests that there is a decreasing trend in the workload of individual audit partners; on average the Big 4 firms staffing ratio is lower as compared with non-big 4 which may indicate that Big 4 partners have less workload. The study is useful for policy makers and regulators to better analyze the audit market concentration and workload in Malaysia.
\end{abstract}

\section{Introduction}

Over the past four decades, because of consolidations and other events, we have seen decline in the number of big global audit firms from eight to four. The majority of large global corporations use the Big 4 accounting firms for auditing their financial statements. In the United States, these firms collectively audit approximately 82 percent of the total market capitalization (GAO, 2008). In most European countries, the audit market of publicly traded companies is also highly concentrated. Based on a recent report by the European Commission (EC) the Big 4 performs almost 70 percent of the statutory audits of public interest entities. For the year 2015, these firms considerably dominated the audits of United Kingdom's FTSE 100 and FTSE 250 index companies (Consultancy.uk, 2018). In Malaysia the Big 4 share was 56.63 percent in 2008, based on the number of audits (Abidin \& Mohamad-Nor, 2016).

It considered that the level of concentration in the audit market is important; investors have raised concerns as to whether the concentrated market power results in lower quality audits and reduce 
investors' protection. The EC has specified in their audit regulation drafts (2011a, 2011b), that growing supplier concentration for audit services at the European audit market is a serious threat. The term "market concentration" describes the agglomeration of economic power, which is present in various industrial sectors, and has diverse effects (Moeller \& Hoellbacher, 2009). Similar to the situation in the UK, the increasing international audit market concentration put the Malaysian audit firms under the radar of the Competition Commission of Malaysia (MyCC), which established to inflict the Anti Competition Law of 2012. Another issue related to the quality of audit services appeared in recent years is the auditor workload. By taking on too many clients, the auditors may lose the ability to carry out every audit in line with the generally accepted auditing standards (GAAS); in result, the violation of ethical pronouncements regarding competency and due diligence could compromised. A study by Persellin et al. (2014) found that the excessive workload of each individual auditor was likely to influence the quality of the audit and could be a "root cause" of audit deficiencies. This ethical tumble of auditors has blamed for many corporate collapses, including Arthur Anderson's failure to detect corporate fraud (Staubus, G. J., 2005).

This study intends to look into these issues with the perspective of Malaysia, as it is one of the biggest capital markets of Asia. The selected period of 2012-2016 is preferred to observe the recent audit market concentration and ranking of the large audit firms. In spite of the importance of audit market concentration and auditor workload, not many studies have examined these issues about Malaysia. This study tries to explore the audit market concentration and auditor workload with distinction. The concentration and staffing ratios applied to analyze the market structure and workload situation of auditors. Additionally, the audit firms ranking by ACE and Main markets also presented.

\section{Background and Previous Literature}

The market concentration is a criterion used to rank various distributions of firms or groups of firm's shares of the total production, total capacity or total services in a market. During the past two decades, several mergers e.g. Peat Marwick Mitchell merger with KMG in 1987, Ernst \& Whiney merger with Arthur Young in 1989 and Coopers \& Lybrand merger with PriceWaterhouse in 1998 reduced the number of big audit firms from eight to five. The Big 5 became the Big 4 after the fall of another big audit firm Arthur Andersen in 2002, following its connection with the Enron scandal. In today's date Deloitte, PriceWaterhouseCoopers, Ernst \& Young and KPMG are the Big 4 audit firms in the world. Based on the global annual revenue of the year 2018, Deloitte maintains its top position globally since 2013 with record revenue of $\$ 43.2$ billion. PriceWaterhouseCoopers is very close to Deloitte and holds second position with $\$ 41.3$ billion. The Earnst \& Young and KPMG are at third and fourth positions with the revenue of $\$ 34.8$ billion and $\$ 29.0$ billion, respectively. Next to Big 4, BDO is the fifth largest accounting firm in the world with the revenue of $\$ 8.99$ billion and 10.7 percent annual growth.

As the number of big audit firms remains half, it increases the concentration in audit market in most of the countries. It has estimated that the Big 4 had about 67 percent share of the global accountancy market in 2012 (Pakaluk, J., 2017). In the United States, the share of Big 4 has also increased overtime (Dunn et al., 2011). Pakaluk (2017) revealed that Big 4 audit cover 99 percent of the S\&P 500 of market index, which covers five hundred large companies by market capitalization listed on the NYSE or NASDAQ exchanges. Despite a series of European Union (EU) and United Kingdom (UK) reforms, which aimed to tackle the lack of competition since the financial crisis of 2008; the Big 4's share of FTSE 350 companies audit rose from 95 percent to 98 percent in 2018. In Australia and New Zealand, the Big 4 also hold a significant share of the market on the basis of the number of audits. UK's policymaker and regulators continuous pressure to break up the Big 4 oligopoly nevertheless, the top accounting and advisory providers remain the same in the audit market after the first quarter of 2018. Doubts regarding both monopolization and conflicting interests have grown throughout the year 2018, in the meantime concern for the collapse of any of the Big 4 also be very detrimental for the market. 
Similar to the concern of the USA and UK's accounting bodies e.g. PCAOB and Financial Reporting Council (FRC) UK; the audit market in Malaysia was also of oligopolistic as examined by Abidin and Mohamad-Nor (2016). There are at least two concerns with this consolidation of audit firms; (1) fewer competitors may lead to higher prices and (2) less competition may lead to a lower quality product or service. In the case of auditing, the higher concentration could lead to complacency and gratification, as auditors realize that clients have very few audit firms to choose. This can lead to a less skeptical approach for auditing. According to the US Government Accountability Office (2008), "Addition to the potential of dominant competitors to use their market power to charge uncompetitive prices, highly concentrated markets also raise other competitive concerns".

In Malaysian context, Abidin and Mohamad-Nor (2016) showed that, top 10 firms dominate the audit market of Malaysia in 2009. The Ernst \& Young was leading the market by having the share of 26.8 percent in 2008 and 25.5 percent in the year 2009. With the share of 14.05 percent in 2009, KPMG held the number two position. One of the non-big 4 was at number three in Malaysia with the total share of clients 9.61 percent in 2009. PWC hold the fourth position with 8.16 percent share of audit market in the subsequent year. The total share of Big 4 in 2009 was 53.4 percent, which was less than the US and UK audit markets. The Concentration ratio CR4 in 2009 was 57.34 percent and CR8 was 75.93 percent in Malaysia. The study showed that Malaysian audit market was also very much concentrated or oligopolistic; this could lead to uncompetitive pricing or a lower quality service. To achieve independent and high quality audits, in 2010 the audit oversight board (AOB) was established in Malaysia. However, it helps to increase the audit practices but still there are many concerns about the audit quality in Malaysia (AOB, 2017). Therefore, it was interesting to examine the current audit market concentration and to see that AOB improves the market structure in Malaysia.

Furthermore, evidence collected by MIA (2018) with respect to auditors' compliance with auditing standards, reveals that many practitioners struggle to comply with the increasingly complex and prescriptive audit standards and audit firms facing the challenge of staff retention due to high demand for accountants in other sectors. This leads to excessive workload for existing auditors. Previous studies also suggest that individual audit partners with more workload are likely to have a bearing on the audit quality (Gul et al., 2017; DeFond\& Zhang, 2014). A recent study by Wan Hussin et al. (2018) argues that auditors observed to prolong audit reports lag, due to the busy schedule. Partner level audit quality research is limited to data because it requires the audit report to be signed by the audit partner with their name disclose in the report. However, fortunately in Malaysia such data is available. This study introduces the staffing ratio to examine the auditor workload as the higher staff to client ratio indicates the excessive workload.

\section{Dataset and Measurements}

The dataset used in the present study covers all companies listed on the Bursa Malaysia including Main and ACE markets and those delisted during the sample period. The study used five years data from 2012 to 2016 on audit firms and partners of each of the 4506 observations of Public Listed Companies on Bursa Malaysia. All the information required were hand-collected from the individual company's annual reports. We also used online sources for the information, which was missing. The study employed the following ratios to determine the market concentration and auditor workload:

\subsection{Audit Market Concentration}

A concentration ratio is the ratio of the combined market shares of a given number of firms to the whole market size. In this study the market share of each firm is calculated based on the number of clients audited in the given year (Abidin et al., 2010; Karim, 2010; Dunn et al., 2011 and Abidin \& MohamadNor, 2016). The most common concentration ratios are the CR4 and the CR8, which depicts the market share of the top four and top eight firms. The $n$ firm concentration ratio measures the proportion of total share in the market hold by a given number of the largest firms in the industry. It is calculated as follows: 


$$
C R_{n}=\frac{\sum_{i=1}^{n} x_{i}}{\sum_{i=1}^{N} x_{i}} \times 100
$$

where: $C R=$ concentration ratio; $n=$ the number of largest firms considered; $N=$ the number of audit firms in the market; $x_{i}=$ the share of the audit firm (based on number of audits).

\subsection{Auditor Workload}

Staffing theory focused on the idea that when there are fewer people available for a number of behavioral settings, there is a pressure on individuals to take on responsibilities (Barker \& Gump, 1964). The client to staff ratio used in many studies across different sectors previously, as the low client to staff ratio indicates better performance and improves the interaction between clients and staff (Felce et al., 1991). This study measures the partner workload by using this ratio as follows:

$$
S R=\frac{\sum_{i=1}^{k}}{\sum_{i=1}^{n}} \times 100
$$

where: $S R=$ staffing ratio; $k=$ number of partners affiliated with the audit firm; $n=$ total number of clients firm audited in the given year.

\section{Results and Discussions}

Table 1 shows the details of market listings of public companies in stock exchange, based on the annual reports available on the Bursa Malaysia (stock exchange) website. The Companies on Bursa Malaysia are listed under either the Main or ACE Markets. The Main market with its streamlined processes and rules usually reserved for larger and more established companies. In the year 2012, almost 910 companies listed into Bursa Malaysia in which 747 companies listed on the Main market and 96 were under ACE market. The number reduced slightly in 2013, consists of 904 companies including 759 Main market and 97 ACE market companies. In 2014 and 2015, 899 and 892 companies listed on the Bursa Malaysia, respectively. The number of Main and ACE market companies was increased in 2016 and only 9 companies were delisted in that year which is a good sign for the market sustainability. On average almost 900 companies were listed on the stock exchange throughout the sample period.

Table 1

Market listing of sample companies in Bursa Malaysia

\begin{tabular}{lcccccc}
\hline \multirow{2}{*}{ Market } & \multicolumn{9}{c}{ Year } & Total \\
\cline { 2 - 6 } & $\mathbf{2 0 1 2}$ & $\mathbf{2 0 1 3}$ & $\mathbf{2 0 1 4}$ & $\mathbf{2 0 1 5}$ & $\mathbf{2 0 1 6}$ & 495 \\
ACE & 96 & 97 & 100 & 100 & 102 & 3831 \\
MAIN & 747 & 759 & 766 & 769 & 790 & 69 \\
DELISTED & 19 & 15 & 11 & 15 & 9 & 111 \\
NA & 48 & 33 & 22 & 8 & 0 & 4506 \\
\hline Total & 910 & 904 & 899 & 892 & 901 & 4 \\
\hline
\end{tabular}

Note: NA stands for the firms which market listing information is not available on Bursa Malaysia

\subsection{Audit Firms Share}

Table 2 presents the share of audit firms of the Malaysian public listed companies in percentage. On average Earnst \& Young, held 19.8 percent share of the market and is the leading audit firm since 2012. KPMG is the second largest audit firm of Malaysia with 13.8 percent average share from 2012 to 2016. With 11 percent share Crowe Horwath becomes the third largest firm in the Malaysian audit market. Another non-big 4 firm Baker Tilly is in Malaysian top 4 with 7.2 percent audits. The Big 8 firms control the audit market of Malaysia as on average 77 percent of market captured by them. 
Table 2

Audit firm's share percentage by number of audits

\begin{tabular}{lcccccc}
\hline \multirow{2}{*}{ Audit Firm } & & \multicolumn{3}{c}{ Year } & \multicolumn{3}{c}{ Total } \\
\cline { 2 - 5 } & $\mathbf{2 0 1 2}$ & $\mathbf{2 0 1 3}$ & $\mathbf{2 0 1 4}$ & $\mathbf{2 0 1 5}$ & $\mathbf{2 0 1 6}$ & \\
\hline EARNST \& YOUNG & 23 & 21.6 & 19.9 & 18.5 & 16.2 & 19.8 \\
KPMG & 13.6 & 13.4 & 14.3 & 14 & 13.7 & 13.8 \\
CROWE HORWATH & 11 & 10.4 & 11.7 & 10.9 & 11.1 & 11 \\
BAKER TILLY & 6.6 & 6.9 & 7.3 & 7.6 & 7.5 & 7.2 \\
PRICEWATERHOUSECOOPERS & 6.4 & 7 & 6.7 & 6.7 & 6.5 & 6.7 \\
BDO & 6.2 & 6.3 & 6.1 & 6.3 & 7.8 & 6.5 \\
GRANT THORNTON & 6.3 & 6.2 & 6.1 & 6.6 & 6.5 & 6.3 \\
DELOITTE & 5.3 & 5.4 & 5.3 & 6.2 & 6.5 & 5.7 \\
S Big 8 & $\mathbf{7 8 . 4}$ & $\mathbf{7 7 . 2}$ & $\mathbf{7 7 . 4}$ & $\mathbf{7 6 . 8}$ & $\mathbf{7 5 . 8}$ & $\mathbf{7 7}$ \\
UHY & 2.3 & 3.1 & 4.1 & 5 & 6 & 4.1 \\
MORISON ANUARUL AZIZAN CHEW & 1.3 & 1.1 & 1 & 1.6 & 1.7 & 1.3 \\
OTHER & 18 & 18.6 & 17.5 & 16.6 & 16.5 & 17.6 \\
Total & $\mathbf{1 0 0}$ & $\mathbf{1 0 0}$ & $\mathbf{1 0 0}$ & $\mathbf{1 0 0}$ & $\mathbf{1 0 0}$ & $\mathbf{1 0 0}$ \\
\hline
\end{tabular}

Fig. 1 shows the trend of Malaysian audit market. As we can observe, the Earnst\& Young considerably reduced the number of clients but still dominating the market since 2012. KPMG and Crowe Horwath are almost consistent with their market share. Interestingly Baker Tilly raises its clients' base and becomes as one of the top 4 audit firms in Malaysia. BDO and Deloitte also increased their market share in Malaysia. Another significant audit firm of is UHY who really stands out among the other audit firms. In 2012, the market share of UHY was 2.3 percent, which rose up to 6 percent until 2016.

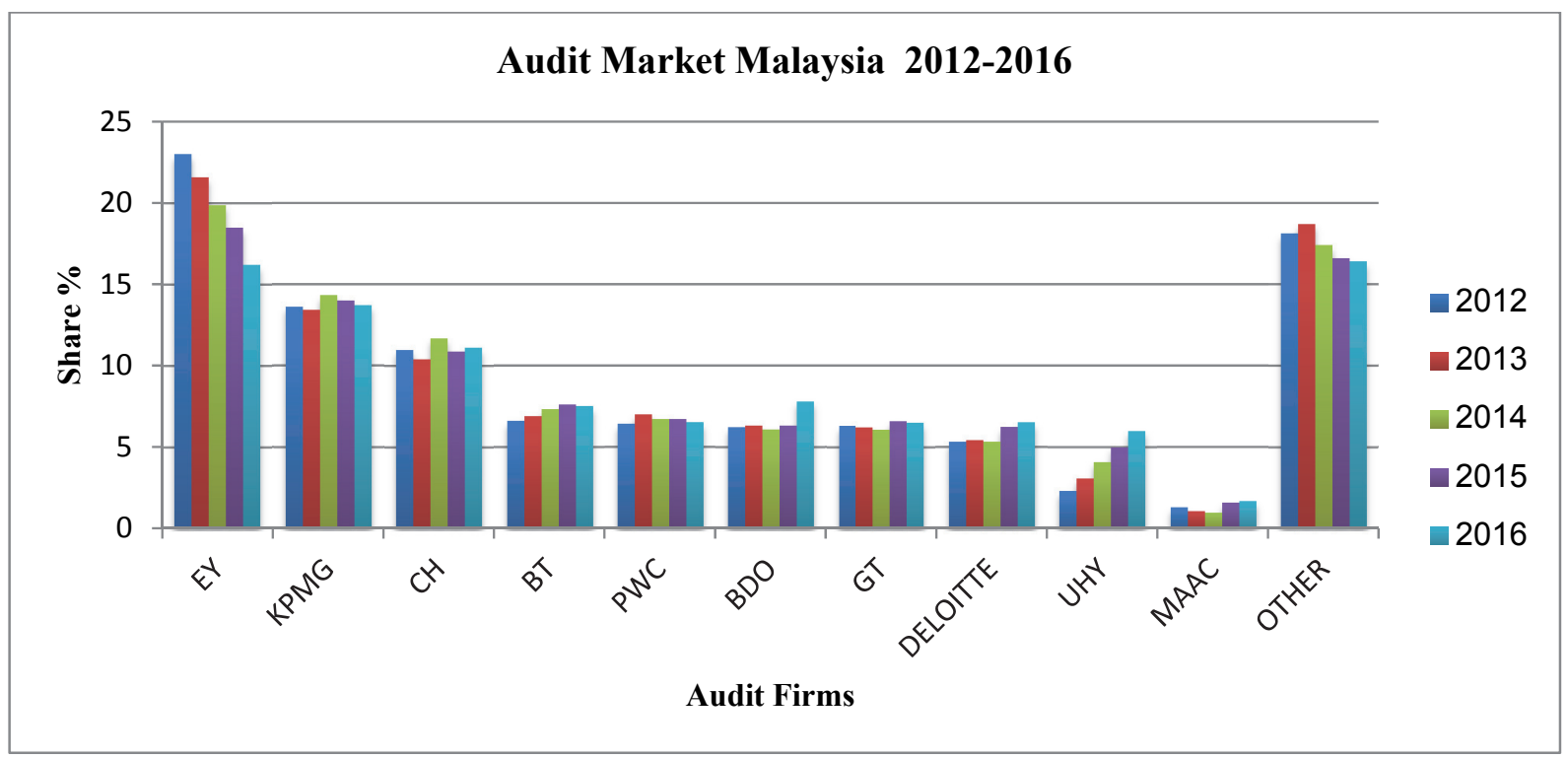

Note: EY is Earnst\& young; CH is Crowe Horwath; BT is Baker Tilly; GT is Grant Thornton; MAAC is Morison Anuarul Azizan Chew

Fig. 1. Audit market share in Malaysia from 2012 to 2016 based on audits

As known, the public companies listed on the ACE and Main markets of Bursa Malaysia so we checked the share of both markets separately. The companies in the ACE market are small and less established as compared with the Main market. The Main market is more stable and have major share of listed companies. Table 3 shows that the main market of Bursa Malaysia is dominated by the Big 4 firms. 
This can be for two reasons, the big audit firms avoid taking risky clients or they charge high audit fee as compared with non-big 4.

Table 3

Audit firms share of the Main market

\begin{tabular}{|c|c|c|c|c|c|c|}
\hline \multirow{2}{*}{ Audit Firm } & \multicolumn{5}{|c|}{ Year } & \multirow{2}{*}{ Tota } \\
\hline & 2012 & 2013 & 2014 & 2015 & 2016 & \\
\hline ERNST \& YOUNG & 187 & 181 & 166 & 155 & 140 & 829 \\
\hline KPMG & 114 & 116 & 124 & 121 & 121 & 596 \\
\hline CROWE HORWATH & 75 & 73 & 86 & 84 & 90 & 408 \\
\hline PRICEWATERHOUSECOOPERS & 53 & 59 & 56 & 57 & 58 & 283 \\
\hline BAKER TILLY & 48 & 51 & 53 & 54 & 57 & 263 \\
\hline $\mathrm{BDO}$ & 44 & 48 & 47 & 45 & 58 & 242 \\
\hline DELOITTE & 39 & 40 & 44 & 50 & 52 & 225 \\
\hline GRANT THORNTON & 39 & 39 & 38 & 42 & 48 & 206 \\
\hline UHY & 16 & 21 & 24 & 33 & 40 & 134 \\
\hline MAAC & 9 & 8 & 8 & 13 & 12 & 50 \\
\hline OTHER & 123 & 123 & 120 & 115 & 114 & 595 \\
\hline Total & 747 & 759 & 766 & 769 & 790 & 3831 \\
\hline
\end{tabular}

On the other hand, non-big 4 audit firms dominates the ACE market of Bursa Malaysia. Table 4 shows the share of audit firms in respect to ACE Market. As expected, the market is significantly taken by the non-big 4 and other small audit firms. The Crowe Horwath, Grant Thornton, Baker Tilly and UHY are the top 4 audit firms in respect of ACE market. One of the non-big 4 audit firms, UHY attracts many clients in the ACE market, and its share considerably increased from 2012 to 2016.

Table 4

Audit firms share of the ACE market

\begin{tabular}{|c|c|c|c|c|c|c|}
\hline \multirow{2}{*}{ Audit Firm } & \multicolumn{5}{|c|}{ Year } & \multirow{2}{*}{ Total } \\
\hline & 2012 & 2013 & 2014 & 2015 & 2016 & \\
\hline CROWE HORWATH & 18 & 16 & 14 & 11 & 9 & 68 \\
\hline GRANT THORNTON & 13 & 13 & 14 & 15 & 10 & 65 \\
\hline BAKER TILLY & 8 & 8 & 11 & 12 & 10 & 49 \\
\hline UHY & 4 & 7 & 12 & 12 & 14 & 49 \\
\hline $\mathrm{BDO}$ & 6 & 5 & 6 & 9 & 11 & 37 \\
\hline DELOITTE & 5 & 5 & 4 & 5 & 7 & 26 \\
\hline ERNST \& YOUNG & 6 & 4 & 4 & 3 & 3 & 20 \\
\hline KPMG & 3 & 3 & 3 & 2 & 1 & 12 \\
\hline MAAC & 2 & 1 & 1 & 1 & 3 & 8 \\
\hline OTHER & 31 & 35 & 31 & 30 & 34 & 161 \\
\hline Total & 96 & 97 & 100 & 100 & 102 & 495 \\
\hline
\end{tabular}

\subsection{Audit Firms Ranking}

Table 5 shows the ranking of audit firms in Malaysia based on audit market share. The Earnst \& Young holds the top position since 2012 followed KPMG. The Crowe Horwath is the third largest audit firm of Malaysia based on number of audits from 2012 to 2016. There was a competition for the fourth position between Baker Tilly and PriceWaterhouseCoopers but on average Baker Tilly is the fourth largest audit firm of Malaysia. The Grant Thornton and BDO strive for sixth position and Deloitte continuously holds the eighth place. UHY is another big audit firm with rank 9 in Malaysia. 
Table 5

Audit firms ranking by number of audits

\begin{tabular}{lccccc}
\hline \multirow{2}{*}{ Audit Firm } & \multicolumn{3}{c}{ Year } & \multicolumn{2}{c}{} \\
\cline { 2 - 6 } & $\mathbf{2 0 1 2}$ & $\mathbf{2 0 1 3}$ & $\mathbf{2 0 1 4}$ & $\mathbf{2 0 1 5}$ & $\mathbf{2 0 1 6}$ \\
\hline EARNST \& YOUNG & 1 & 1 & 1 & 1 & 1 \\
KPMG & 2 & 2 & 2 & 2 & 2 \\
CROWE HORWATH & 3 & 3 & 3 & 3 & 3 \\
BAKER TILLY & 4 & 5 & 4 & 4 & 5 \\
PRICEWATERHOUSECOOPERS & 5 & 4 & 5 & 5 & 6 \\
GRANT THORNTON & 6 & 7 & 7 & 6 & 7 \\
BDO & 7 & 6 & 6 & 7 & 4 \\
DELOITTE & 8 & 8 & 8 & 8 & 8 \\
UHY & 9 & 9 & 9 & 9 & 9 \\
MORISON ANUARUL AZIZAN CHEW & 10 & 10 & 10 & 10 & 10 \\
\hline
\end{tabular}

\subsection{Concentration Ratio}

Table 6 reports the level of audit market concentration from 2012 to 2016. Focusing on the concentration statistics measured by number of audits, the level of audit market concentration in Malaysia during the period has considered high, but not as high as in developed markets. Generally, the $n$-firm concentration reflects a decrease in concentration in 2016 as compared with 2012 . The only exception is for the CR10 based on number of clients, indicating that the top ten firms have managed to increase their clients, albeit marginally. In 2008, the top four and Big 4 firms audited around 57.58 percent and 56.63 percent of the market as reported by Abidin and Mohamad-Nor, (2016), which reduced to 48.50 percent and 42.95 percent in 2016, respectively. Though, the market concentration is significantly reduced in Malaysia from 2008 to 2016, but still considered oligopolistic market, as concentration of market more than 40 percent considered loose oligopoly. Usually, the economists defined the market loose oligopoly, where the CR4 vary between 40 percent to 60 percent, and if the CR4 > 60 percent deem as tight oligopoly. The Malaysian audit market is relatively competitive than the other developed markets like UK and USA. It becomes more attractive for small audit firms e.g. UHY and MAAC who succeed to make their space in the top 10 but it also raise the concern for audit quality as small firms face lack of staff and resources.

Table 6

Concentration ratio measured by number of audits

\begin{tabular}{lccccc}
\hline \multirow{2}{*}{ Concentration Ratio } & \multicolumn{5}{c}{ Year } \\
\cline { 2 - 6 } & $\mathbf{2 0 1 2}$ & $\mathbf{2 0 1 3}$ & $\mathbf{2 0 1 4}$ & $\mathbf{2 0 1 5}$ & $\mathbf{2 0 1 6}$ \\
\hline CR4 & $54.18 \%$ & $52.21 \%$ & $53.28 \%$ & $51.01 \%$ & $48.50 \%$ \\
CR6 & $66.70 \%$ & $65.49 \%$ & $66.07 \%$ & $64.01 \%$ & $62.82 \%$ \\
CR8 & $78.24 \%$ & $77.10 \%$ & $77.53 \%$ & $76.80 \%$ & $75.92 \%$ \\
CR10 & $80.55 \%$ & $80.20 \%$ & $81.65 \%$ & $81.84 \%$ & $81.91 \%$ \\
CR Big4 & $48.24 \%$ & $47.68 \%$ & $46.27 \%$ & $45.40 \%$ & $42.95 \%$ \\
\hline
\end{tabular}

\subsection{Audit Firm Workload}

The staffing ratio is an indicator of workload; Table 7 reports the staffing ratio of top 10 audit firms of Malaysia as on 2016. As MIA (2018), indicate that audit quality suffering in Malaysia because of lack of staff and resources, we measure the staffing ratio. The PriceWaterhouseCoopers maintains the lowest client to staff ratio throughout the sample period. Ernst \& Young and Crowe Horwath partners audit almost 4 client on average in the year 2016. The results indicate that small audit firms e.g. Baker Tilly and UHY clients to partner ratio is relatively quite high. Because, the small audit firms are more suffering from lack of staff as compared to top 4. Persellin et al. (2014) find out that auditors perceive workload fatigue have the significant adverse impact on morale and understaffing and staff turnover as being two of the biggest obstructions for delivering a high quality audit. 
Table 7

Staffing Ratio of top 10 Audit Firms

\begin{tabular}{|c|c|c|c|c|c|}
\hline \multirow{2}{*}{ Audit Firm } & \multicolumn{5}{|c|}{ Year } \\
\hline & 2012 & 2013 & 2014 & 2015 & 2016 \\
\hline EARNST \& YOUNG & 5.97 & 5.57 & 4.97 & 4.58 & 3.84 \\
\hline KPMG & 4.59 & 4.17 & 4.61 & 5 & 4.24 \\
\hline CROWE HORWATH & 5.88 & 5.22 & 5.53 & 4.41 & 3.85 \\
\hline BAKER TILLY & 7.5 & 6.89 & 8.25 & 11.33 & 13.6 \\
\hline PRICEWATERHOUSECOOPERS & 2.9 & 2.86 & 3.16 & 3.16 & 2.81 \\
\hline $\mathrm{BDO}$ & 7 & 5.18 & 5 & 5.09 & 5.83 \\
\hline GRANT THORNTON & 6.33 & 5.09 & 4.58 & 4.92 & 4.92 \\
\hline DELOITTE & 3.69 & 4.08 & 3.43 & 4.23 & 4.21 \\
\hline UHY & 4.2 & 4 & 5.29 & 7.5 & 6.75 \\
\hline MORISON ANUARUL AZIZAN CHEW & 4 & 3.33 & 4.5 & 7 & 7.5 \\
\hline
\end{tabular}

\subsection{Audit Partner Workload}

Fig. 1 shows the workload trend of top 20 individual audit partners from 2012 to 2016. Most of the partners range within 10 to 15 audits per year in 2012 except "Heng Ji Keng". The graph clearly shows the downward trend in the audit partner workload. During the year 2016, the average number of audits falls into the range of 5 to 10 . This may be due to the concerns of regulators and stakeholders regarding the individual partners' workload impact on audit quality. In this aspect, Defond and Zhang (2014) argues that busy auditors may not be able to achieve the best audit practices.

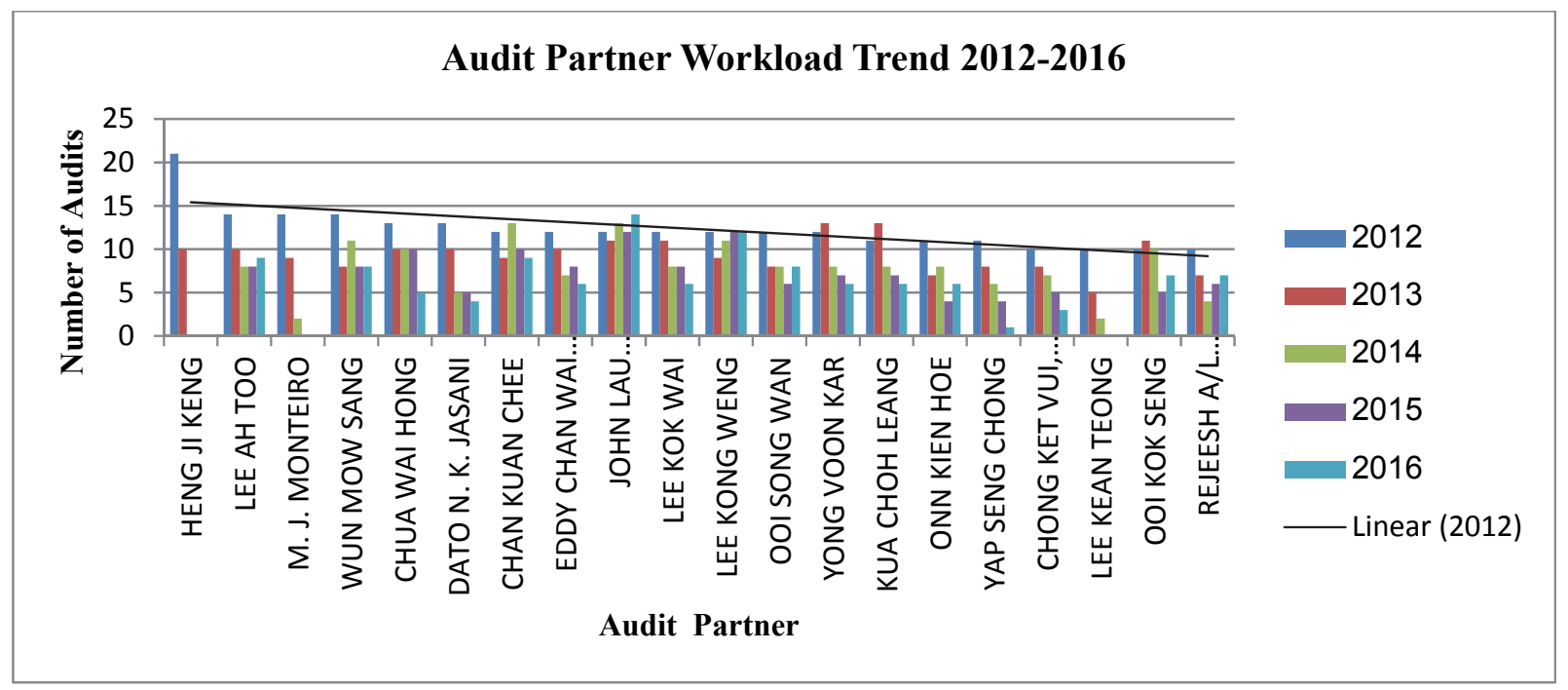

Fig. 2. Audit partner workload trend in Malaysia from 2012 to 2016

\section{Conclusion}

This study looks at the overall Malaysian audit market concentration and auditor workload. Based on the average of five years from 2012 to 2016, the top 4 audit firms in Malaysia are Earnst \& Young, KPMG, Crowe Horwath and Baker Tilly. PriceWaterhouseCoopers is the fifth largest audit firm in Malaysia; in general eight firms dominate the audit market of Malaysia. These firms executed almost 75.8 percent of the audits in 2016 . The results indicated the oligopoly market structure, but as compared with other developed countries, Malaysian audit market is less concentrated. In UK, Beattie et al. (2003) reported that the Big 4 had a market share of almost 73 percent, and currently it is about 70 percent. Moreover, in USA Big 4 share is 67 percent and increasing overtime (GAO, 2008). The study results are consistent with the findings of Abidin and Mohamad-Nor, (2016) that audit market of Malaysia is 
oligopolistic but there is significant decrease in the concentration. Interestingly global 4 are not top 4 in Malaysia, as Crowe Horwath continuously hold the third position since 2012 and Baker Tilly also raises its client's base by surpassing PriceWaterhouseCoopers. The reason for this maybe because Big 4 avoid to take risky clients and only focus on more established companies and also because of the low audit fee in Malaysia as compared with other developed countries (MIA, 2018).

In many firms, the staff ratio calculated to know the workload of employees. The type of work dictates the best value for staffing ratio, usually no generalization. In this regard, the Big 4 stands out as compared with non-big 4 firms. PriceWaterhouseCoopers have the lowest staffing ratio following by Earnst \& Young. Staffing theory suggests that the lower staff ratio means the better services. It indicates that the services provided by the Big 4 maybe comparatively more reliable and accurate as compared with non-big 4. Previously there is no such study, which measures the staffing ratio for auditor workload. Prior studies examined the audit partner workload and consider of it as bearing for the audit and financial reporting quality (DeFond \& Zhang, 2014). Further, we check the workload trend of top 20 auditors in 2012. The result shows that there is a decreasing trend in the partner workload over the years. The regulators and policy makers are becoming more concerned about this issue.

There are several limitations encountered in this study also. First, we have examined the market share based on the number of audits perfumed by these firms in the given year. To understand better the market share as a whole, audit fee is also an important measurement of market concentration as suggested by previous studies. Second, the study did not examine the partner workload empirically that can affect audit or reporting quality; this study shows the average number of audits per partner the audit firms have. Third, the study presented auditor workload trend for top 20 auditors in 2012 and maybe it is not appropriate to generalize. The future studies can explore these issues more to see a better view of the audit market and auditor workload. In general, Malaysia proposes a distinctive example of audit practices for the emerging Asia Pacific countries, which may be dissimilar from other developed countries.

\section{References}

Abidin, S., Beattie, V., \&Goodacre, A. (2010). Audit market structure, fees and choice in a period of structural change. British Accounting Review, 2(3), 187-206.

Abidin, S., \& Mohamad-Nor, M. N. (2016). Competition in Malaysian audit industry: what the market is telling us?. Mediterranean Journal of Social Sciences, 7(1), 306.

Audit Oversight Board. (2018). 2017 annual report of the Malaysian Audit Oversight Board. Retrieved from https://www.sc.com.my/api/documentms/download.ashx?id=b1b07a7f-8 ce0-4db7 -9bcf-f87f7e5965b2

Beattie, V., Goodacre, A., \&Fearnley, S. (2003). And then were four: A study of UK audit market concentration. Journal of Financial Regulation and Compliance, 11(3), 250-265.

Barker, R. G., \& Gump, P. V. (1964). Big school, small school: High school size and student behavior. American Psychological Association, Washington. Retrieved from https://psycnet.apa.org/record/1965-02788-000

Consultancy.uk. (2018, June 04). Big four maintains the dominance of FTSE $100 \& 250$ audits. Retrieved from https://www.consultancy.uk/news/17349/big-four-maintains-dominance-of-ftse100-and-250-audits

DeFond, M. and Zhang, J. (2014). A review of archival auditing research. Journal of Accounting and Economics,58(2/3), 275-326.

Dunn, K., Kohlbeck, M., \& Mayhew, B. W. (2011). The impact of the Big 4 consolidation on audit market share equality. Auditing, 30(1), 49-73.

European Commission (2011a). Proposal for a Directive of the European Parliament and of the Council amending Directive 2006/43 / EC on the audits of annual accounts and consolidated accounts. (KOM(2011) 778/2.

European Commission (2011b). The proposal for a Regulation of the European Parliament and of 
the Council makes specific requirements for the final examination of undertakings of public interest. $(\mathrm{KOM}(2011) 779 / 4$.

Felce, D., Repp, A. C., Thomas, M., Ager, A., \& Blunden, R. (1991). The relationship of staff: client ratios, interactions, and residential placement. Research in Developmental Disabilities, 12(3), 315 331.

Gul, F.A., Ma, S.M.,\& Lai, K. (2017). Busy auditors, partner-client tenure, and audit quality: evidence from an emerging market. Journal of International Accounting Research, 16(1), 83-105.

Karim, A.K.M.W. (2010, Feb 23). Audit Pricing, Audit Concentration, and Big-4 Premium in Bangladesh. SSRN: https://ssrn.com/abstract $=1613454$

MIA. (2018, Sep). The Audit Profession in Malaysia 2018. Malaysian Institute of Accountants, Kualalumpur.https://www.mia.org.my/v2/downloads/resources/publications/surveillance practice/2018/MIA_The_Audit_Profession_2018.pdf

Moeller, M., \&Hoellbacher, A. (2009). The German stock market and index landscape and the market maker's final examinations. Die Betriebswirtschaft, 69(6), 647-678.

Pakaluk, J. (2017, Feb 27). Audit Analytics. Retrieved from https://www.auditanalytics.com/ blog/auditor-market-share-of-the-sp-500/

Persellin, J., Schmidt, J., \& Wilkins, M. S. (2014). Auditor perceptions of audit workloads, audit quality, and the auditing profession.Digital Commons@ Trinity.doi: 10.2139/ssrn.2534492

Staubus, G. J. (2005). Ethics failures in corporate financial reporting. Journal of Business Ethics, 57(1), $5-15$.

US General Accounting Office. (2008). Audits of the public companies: Concentration in audit market for large public companies does not call for immediate action. https://www.gao.gov/reportstestimonies/

Wan Hussin, W. N., Bamahros, H. M., \&Shukeri, S. N. (2018). Lead engagement partner Workload, partner-client tenure and audit reporting lag: Evidence from Malaysia. Managerial Auditing Journal, 33(3), 246-266.

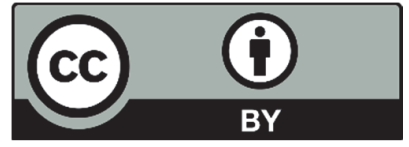

(C) 2019 by the authors; licensee Growing Science, Canada. This is an open access article distributed under the terms and conditions of the Creative Commons Attribution (CC-BY) license (http://creativecommons.org/licenses/by/4.0/). 